\section{COLLABORATIVE GOVERNANCE}

\section{REGIMES IN ILLIBERAL DEMOCRACIES:}

\section{A COMPARATIVE CASE OF DRUG}

\section{HARM REDUCTION POLICY}

IN CENTRAL-EASTERN EUROPE

\section{György HAJNAL Iga JEZIORSKA}

\section{György HAJNAL}

Professor, Institute of Economic and Public Policy, Corvinus University of Budapest, Budapest, Hungary Research Chair of Public Policy and Governance, Institute for Political Science, Centre for Social Research of the Hungarian Academy of Sciences (IPS CSR HAS), Budapest, Hungary

Tel.: 0036-1-482.5032 ext.: 5032

E-mail: gyorgy.hajnal@uni-corvinus.hu

Iga JEZIORSKA (corresponding author)

$\mathrm{PhD}$ candidate, Institute of Economic and Public Policy, Corvinus University of Budapest, Budapest, Hungary

Tel.: 0036-1-482.5032

E-mail: iga.jeziorska@uni-corvinus.hu
DOI: $10.24193 /$ tras.62E.4

Published First Online: 02/25/2021 


\section{Introduction}

In recent decades, the practice of governance and the literature on public policy design and implementation have shifted their focus from the state as the central policymaker to more participatory forms (Howlett, 2014, p. 192). One of several concepts exemplifying this general shift is collaborative governance (CG), understood here as the conscious and systematic application of various institutional arrangements for involving non-state actors in policy processes (Ansell and Gash, 2007, p. 544). Recently, this approach has been increasingly deployed in many (Western) countries and policy fields, maybe most prominently in health and social services (Rees, Mullins and Bovaird, 2012) where an increasing number of services are provided through co-production with non-profit sector involvement (Brandsen and Hout, 2006, p. 538).

Turning to Central-Eastern Europe (CEE), however, a markedly different picture appears. First, it is argued that NGOs in CEE are weaker than their Western counterparts, as has been the case since the systemic change in 1989-1990 (Howard, 2003). Besides this 'base-line' difference, however, a new and remarkable trend seems to be emerging in some of the region's countries. As part of a more general turn away from liberal democratic values, virtues and governance practices, it seems that in certain countries of CEE, the (non-deliberate) lack of NGO development and accompanying co-governance practices is evolving into deliberate underdevelopment. Behind this new trend, it is not hard to discern a change in government policy from simple disregard to outright hostility, at least with regard to certain types of NGOs and certain forms of involving them.

Scholars writing about this emerging pattern of development in the region usually focus on two countries: Hungary and Poland. Importantly, both countries are prime examples of a far broader political turn, denoted variously as de-democratization (Ágh, 2015), democratic deconsolidation (Foa and Mounk, 2017), autocratization (Lührmann and Lindberg, 2019), to mention but a few terms, and illiberalism (Hajnal and Rosta, 2016; Zakaria, 1997) ${ }^{1}$.

This new illiberal turn, featuring an apparently determined crackdown on certain NGOs, is still largely unexplored in terms of its implications for CG. Much of the literature on CG refers to it as though it emerges, albeit enabled by the institutional infrastructure and partly driven by the incentive system created by governments, to a significant extent spontaneously. We argue that CG is not necessarily spontaneous; on the contrary, governments can and do undertake conscious actions facilitating or preventing CG. We pursue two closely related ambitions. Firstly, our theoretical

1 We subscribe to the approach of Lührmann and Lindberg (2019), who define autocratization as the most overarching concept, encompassing similar phenomena contexts ranging from autocracies to high-quality democracies. In their view, Hungary falls into the terminological category of 'democratic recession' (p. 1097). Nevertheless, we still prefer to use the term 'illiberal (democracy)' to denote the Hungarian and Polish cases of democratic recession since 'recession' implies a somewhat unintended and spontaneous process which is not the case here. 
ambition is to develop a classification of collaborative governance regimes (CGRs, for conceptualization of the term see section 2.2.). Secondly, we wish to better understand how illiberal governance affects CG.

Below we present a comparative case study of the drug policy areas in four countries in CEE: Czechia, Hungary, Poland and Slovakia. While these countries share many historical, cultural and political features, one essential difference is the recent illiberal turn occurring in Hungary and Poland.

In section 2 we briefly review the relevant parts of the literature dealing with CG, in order to derive a conceptual and analytical framework with which to describe and compare the regimes presented in our examples. To delimit and justify our research objective, in section 3 we summarize the latest research on how NGOs are involved in policymaking in CEE. Section 4 outlines our research question, and the data and method used to answer it. Section 5 presents the empirical findings. The paper concludes with a brief discussion of the results.

\section{Collaborative governance: conceptualization and operationalization}

\subsection{Collaboration, collaborative governance and collaborative governance regimes}

Various forms of governance involving non-state actors have gained scholarly attention in the last three decades. Due to the increasing emergence of wicked policy problems (Head and Alford, 2015), the failure of hierarchical governments to address international issues (Bingham, 2011, p. 386), and criticism of the intra-governmental focus of New Public Management (Osborne, 2006, p. 380), public management has significantly shifted from hierarchical government to more participatory policymaking. Collaborative governance is one of the prominent approaches grasping this shift.

Collaboration, briefly, can be defined as a situation where 'a group of autonomous stakeholders of a problem domain engage in an interactive process, using shared rules, norms, and structures, to act or decide to act on issues' (Gray and Wood, 1991, p. 146), although many other, largely similar definitions exist (Bedwell et al., 2012, p. 130; Bryson, Crosby and Stone, 2006, p. 44).

However, the number of conceptual works on collaborative governance is far lower. While some authors use the term in a narrower sense (Ansell and Gash, 2007) a broader conceptualization defines it as 'the processes and structures of public policy decision making and management that engage people constructively across the boundaries of public agencies, levels of government, and/or the public, private and civic spheres in order to carry out a public purpose that could not otherwise be accomplished' (Emerson, Nabatchi and Balogh, 2012, p. 2). This concept of CG does not imply being initiated by public/governmental actors, nor does it exclude informal arrangements. In this study, we apply this definition.

The concept of collaborative governance regime (CGR) was recently developed by Emerson and Nabatchi (2015) as a reasonably coherent and stable system of government policies and government actions that shape and affect CG. What we call CGR 
corresponds, to a large extent, to Emerson and Nabatchi's (2015) 'system context' (a broader category encompassing the environment where CGR occurs). In other words, in our approach, CGR includes: (i) the political and policy environment of CG, and (ii) the government actions undertaken within CG processes.

Consequently, we attempt to conceptualize and operationalize CGRs which support CG arrangements to a varying extent, including regimes designed to undermine CG development (for details see Table 1). Our analytical framework was developed to enable differentiation between such understood CGRs.

\subsection{Analytical framework}

Based on a broad array of literature describing state - NGO interactions in policymaking, we have identified a number of analytical variables operationalizing key features of CGRs.

The first set of analytical variables includes those describing the political and policy environment of CG.

- Operational space refers to 'possibilities and freedoms for NGOs to operate' (van der Borgh and Terwindt, 2012, p. 1069), and thus includes the extent of state protection of NGOs' rights to make claims vis-à-vis the government, the legal and policy framework and the political context in which NGOs operate.

- System stability relates to the extent to which the operational environment of NGOs and CG (including legal and policy frameworks) is subject to unpredictable, uncontrollable and/or frequent changes. Such changes tend to destabilize the environments in which CG takes place (Bryson, Crosby and Stone, 2006). On the other hand, it is argued that high system stability increases the effectiveness of inter-organizational networks (Provan and Milward, 1995).

The second set of analytical variables refers to substantive features of CG, i.e. the government actions undertaken to initiate and maintain CG processes:

- Mechanisms for involving NGOs in policy formulation and design. In addition to organizational forms, this dimension includes mechanisms (e.g. public consultations, round tables, coordination fora, etc.) for involving NGOs in policy formulation and design.

- Mechanisms for involving NGOs in policy implementation. This dimension includes mechanisms (e.g. tenders, contracting, etc.) for involving NGOs in policy implementation. It also involves factors potentially hindering effective policy implementation.

- Indirect resources variable refers to the non-earmarked financial resources available for NGOs to fulfil their tasks (while revenues received for direct service provision, for example, would be classified differently as direct resources). Such resources come in a variety of forms, e.g. tax concessions (corporate as well as personal income tax) or external (international) funding administered by national governments. Other factors being constant, the munificence of such financial 
resources has a positive impact on the effectiveness of collaborations (although abundant resources alone are no guarantee of effectiveness or efficiency) (Provan and Milward, 1995), and on their sustainability (Sharfman, Gray and Yan, 1991).

- Direct resources refer to the amount of earmarked government funding provided in exchange for specific activities or provision of specific public services (such as direct earmarked financial support or service contracts). Similar to indirect resources, there is a supposed positive relationship between the munificence of direct financial resources and the effectiveness and sustainability of CG. This dimension also includes ways of allocating resources, e.g. transparency and merit-based as opposed to politically or ideologically driven, or clientelist.

- Joint operating procedures refer to the degree to which the two sectors are aligned and mutually adjusted in terms of operations and decision-making processes and procedures aiming to achieve common goals (Tatcher, 2007 apud McNamara, 2012, p. 393), the degree of inclusiveness and participation of various non-governmental stakeholders in decision-making (McNamara, 2012), and measures for the empowerment of the least powerful participants (Bryson, Crosby and Stone, 2006).

- Trust-building: policies and government activities affecting trust ${ }^{2}$ are crucial for CG. Trust-building is facilitated by direct and open communication (McNamara, 2012), shared understanding, commitment as well as reciprocal orientation (Bryson, Crosby and Stone, 2006).

Based on the above variables it is possible, on the basis of their observable features, to locate actual CGRs according to the extent to which they actively promote, disregard, or openly hinder and counteract CG (situations we term, respectively, 'pro-collaborative regime', 'neutral regime' and 'anti-collaborative regime'). To this end, we have developed a prediction matrix (Hak and Dul, 2012), denoting, on the basis of theoretical considerations, specific values for each variable (feature) of the above three types of CGRs.

The summary of the features of the three examined regimes can be found in Table 1.

\section{Illiberalism, collaborative governance and non-governmental organizations in Central-Eastern Europe}

As we argued above, there is ample literature dealing with how different types of organizations operating outside the realm of both government and business are involved in governance in Western European and Anglo-Saxon countries (see, for example, Brandsen and Hout, 2006; Osborne and Strokosch, 2013; Pestoff, 2012). How-

2 We adopt Hosmer's definition of trust widely cited in management scholarship: 'Trust is the expectation by one person, group, or firm of ethically justifiable behavior - that is, morally correct decisions and actions based upon ethical principles of analysis - on the part of the other person, group, or firm in a joint endeavor or economic exchange' (Hosmer, 1995, p. 399). 


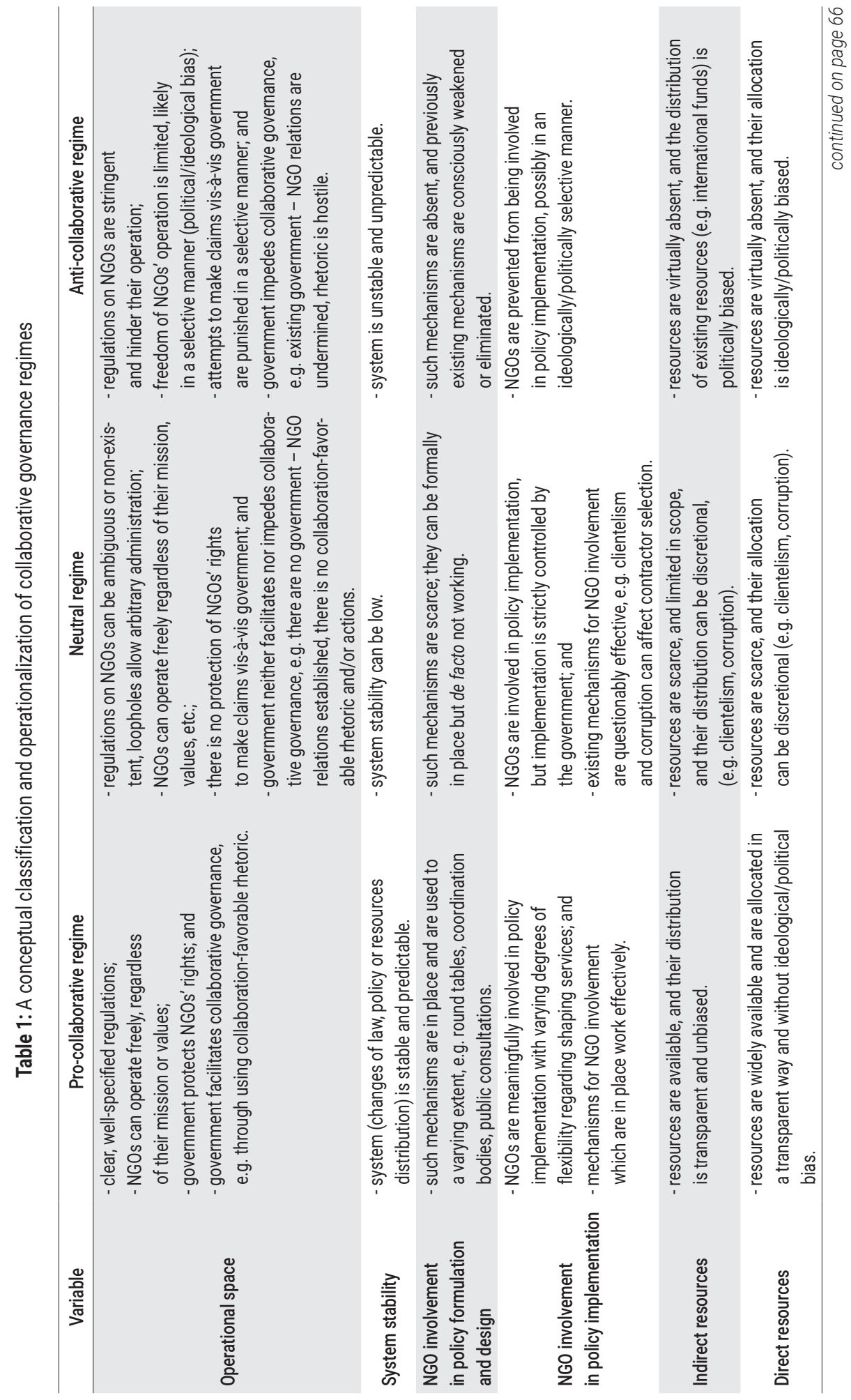




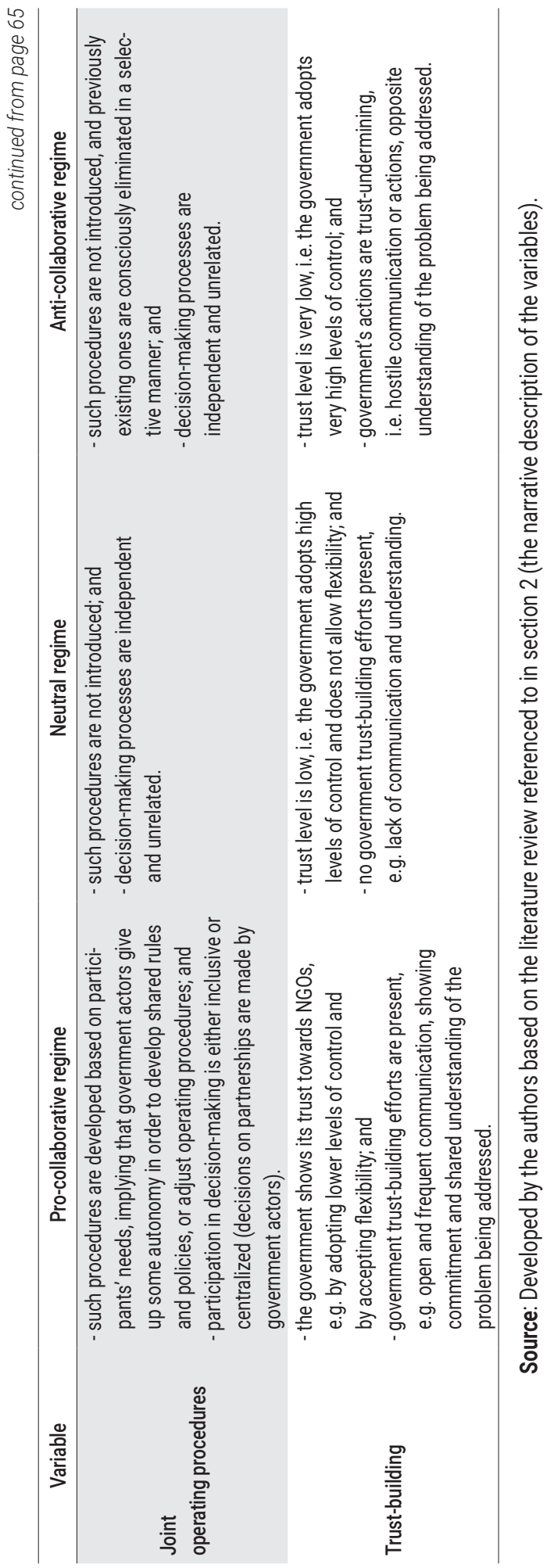


ever, when it comes to CG in CEE, both the practice and the literature are much scarcer, for several reasons.

First, due to shared history of Soviet occupation, and rapid transformation to a market economy and liberal democracy, the countries of CEE - understood here as those in the so-called Visegrád Group - are characterized by cronyism, and the needs and interests of informal groups, rather than actual policy objectives, shape public services (Rupnik and Zielonka, 2012).

Second, over the post-transition decades, there was general consensus that civil society in CEE is weak, especially when compared with its Western counterpart (Howard, 2003), although recently this view has come in for some criticism (Ekiert, 2012).

Third, with respect to the role of NGOs in policymaking, several problems have been identified. NGOs have small membership bases and are chronically underfunded (Börzel, 2010), and policies towards them have been inconsistent (Fric and Bútora, 2003).

Finally, it is argued that civil society and its involvement in policymaking and service provision are also restricted by centralism, with the state as a monopolistic provider of various social and health services (Fric and Bútora, 2003; Rees and Paraskevopoulos, 2006).

The diagnosis has thus been gloomy. However, in the context of the third sector's involvement in policymaking, some of the most recent accounts on participatory policymaking in CEE build up a picture that is gloomier even than the one suggested above.

As part of what seems to be a more global trend, in certain countries of CEE (notably Hungary and Poland), governments increasingly reject liberal democratic principles and values. This new type of politics, frequently referred to as illiberal, involves the appropriation of democratic procedures. Manifestations of this illiberal turn are also visible in the field of CG including NGOs. The attitude towards NGOs and their involvement in public policy has shifted from disregard to outright hostility (Cooley, 2015). Law enforcement is used against NGOs (Grzebalska and Peto, 2018). Organizations opposed to the government are pictured as threats to the nation and as servants of foreign interests (Gerő and Kerényi, 2017).

\section{Research questions, method and data}

\subsection{Research questions}

In the preceding sections we argued, firstly, that in a broader European perspective, recent and contemporary administrative reform practices and reform doctrines generally exhibit an ever-increasing emphasis and reliance on NGOs in designing and delivering public policies and services. Secondly, CEE, while lagging behind in this process, is further characterized by the emergence of a new pattern possibly amounting to a new, coherent doctrine, involving a radical turn away from the above-mentioned ethos of CG. Thirdly, we argued that this turn is (currently) predominantly 
taking place in countries undergoing an illiberal turn, and that this is not mere coincidence, but seems to be an inherent component of illiberal governance practices.

Our two research questions build upon the above arguments and include, firstly, a classification/typologizing ambition (Landman, 2009): what are the ideal types of CGRs? Secondly, how do CGRs within drug harm reduction policy differ in illiberal democracies compared with their non-illiberal (or less illiberal) counterparts in CEE? By answering these questions, we expect to learn whether there is an identifiable illiberal paradigm relating to CG.

\subsection{Data and method}

We apply qualitative comparative case study design combined with congruence analysis (Blatter and Haverland, 2012). This requires (i) developing a typology of collaborative governance regimes; (ii) identifying dimensions (variables) describing collaborative governance regimes and allowing for differentiation and comparison between them; (iii) determining the values of each dimension for each type of collaborative governance regime identified. Taken together, these steps produce a so-called prediction matrix identical to the one in Table 1. Finally, (iv) we classify our cases according to collaborative governance regime type, based on empirical data.

To obtain a detailed analysis anchored in rich empirical evidence within our country cases, we focus on one specific policy field: drug policy. More specifically, we focus on harm reduction responses (so-called low-threshold services ${ }^{3}$ ) for injecting drug users.

Timewise, the analysis focuses on the period 2010-2019, with the exception of the 'system stability' dimension, which, due to its inherently long-term orientation, takes account of the last two decades.

Below we clarify and justify the logic behind our case selection in terms of (i) the countries and (ii) the policy sector chosen for comparison.

The study covers four countries: Czechia, Hungary, Poland and Slovakia. This narrow geographical scope was chosen based on the countries' membership of the Visegrád Group, which, despite being a political entity and not an analytical category, is often the focus of scholars researching Central-Eastern Europe. Notwithstanding many historical and political similarities, these countries differ in one important aspect: the materialization of the illiberal paradigm.

As noted earlier, Hungary and Poland strongly feature illiberal doctrines in their governance transformations since FIDESZ-MPP and Law and Justice formed governments in 2010 and 2015, respectively. Hungary and Poland are often pictured as

3 Low-threshold programs are harm reduction programs with minimal or no demands towards the clients; they include needle exchange, distribution of other materials, social services (counselling, social work) and sometimes health services; limiting/quitting substance use is not a precondition for participating, and use of counselling is voluntary (unlike in high-threshold programs, where it is obligatory). 
illiberal 'drastic cases' (Bochsler and Juon, 2019, p. 16) or 'prominent cases' of 'democratic erosion' (Lührmann and Lindberg, 2019, p. 1105) within the region, while in other countries 'a relatively stable but low-quality democracy is the norm' (Cianetti, Dawson and Hanley, 2018, p. 246). Indeed, Czechia and Slovakia exhibit a large extent of continuity in terms of their governance practices and the ideological and doctrinal underpinnings thereof. According to the Nations in Transit report, in 2020, Hungary was classified as a transitional or hybrid regime, and Poland fell into the 'semi-consolidated democracy' category (Freedom House, 2020, p. 3). Meanwhile, Czechia and Slovakia are still considered consolidated democracies (Freedom House, 2020, p. 12).

Our approach in choosing drug harm reduction policies is similar to a critical case logic (Yin, 2003, p. 40), namely, harm reduction is an (ideal)typical case of a 'wicked' problem that requires the inclusion of - or possibly almost the sole reliance on NGO-type organizations and other non-state actors (Head, 2008). In order to find at least some elements of CG in a context characteristically hostile to such governance practices, it is therefore advisable to inspect this policy and service sector.

Data collection took place between 2015 and 2019. Documentary analysis primarily included the legislation and other subsequent regulations and policy documents of the countries concerned, and reports relevant to our area of interest. Although the existing sources include some information on the formal and legal frameworks and provide a picture of the field, we aimed to supplement and contrast this (official view of CG practices) with the perspectives of NGOs as entities historically being in the center of harm reduction responses. Semi-structured interviews were conducted with 20 employees of harm reduction NGOs working locally. Key-informants were selected using purposive sampling (Tongco, 2007) complemented by the snowball method (Goodman, 1961), and taking into consideration convenience. Interviews were recorded and transcribed verbatim and lasted approximately 90 minutes. The data was hand-coded using qualitative data-analysis software MaxQDA, following a code system based on our analytical framework. Subsequently, synthetic summaries were developed for each case per dimension. These summaries served as the basis for categorizing the countries into one of the three regime types through the pattern-matching procedure described at the beginning of this section.

\section{Empirical findings}

The objective of our analysis is to position each country case along the eight identified dimensions, that is, to decide which ideal type category (pro-collaborative, neutral or anti-collaborative regime) is most appropriate for each case and dimension. To this end, in the following eight subsections - corresponding to the eight analytical dimensions - we present key pieces of evidence for the Czech, Hungarian, Polish and Slovak drug policy situations. 


\subsection{Operational space}

NGOs in Czechia operate under a range of laws addressing various aspects of their activity (ICNL, 2019a). Harm reduction is strongly supported as a pillar of drug policy (Government of the Czech Republic, 2010) and service providing NGOs are officially recognized as social services and are subject to legislation and other subsequent regulations (Parliament of the Czech Republic, 2006). They enjoy a relatively high level of operational freedom and their rights to make claims vis-à-vis government are respected; government politicians exhibit pro-collaborative attitudes towards harm reduction NGOs (KI-13).

In the other three countries, a different picture is suggested by the data. NGOs in Hungary are in the worst position, with politically and ideologically selective restrictions on their operational space, most notably through the law on so-called 'foreign agents', organizations receiving funding from abroad (Hungarian Parliament, 2017). Drug policy focuses on abstinence, and harm reduction, briefly mentioned in the state anti-drug strategy, is clearly not a preferred way of tackling drug use (Hungarian Parliament, 2013). As harm reduction is almost taboo, the environment created by the Government for such NGOs is extremely challenging. Some have suffered attacks and scapegoating campaigns by local authorities, allegedly orchestrated to set an example for others considering making claims vis-à-vis the Government (KI-5). As drug use is criminalized, some of the most important activities of harm reduction NGOs (e.g. needle exchange programs) are vulnerable to accusations of aiding criminal activity.

Significant similarities can be found in Poland and Slovakia. In both countries, the operation of NGOs is regulated by a range of different laws (ICNL, 2019b, 2019c). Regarding official drug policies, Governments support harm reduction as part of their national drug strategies ${ }^{4}$ (Council of Ministers of Poland, 2016; Ministry of Health of the Slovak Republic, 2013). Nevertheless, drug policy is de facto largely disregarded as a policy area, which results in a non-supportive environment for CG in this area (KI-4, KI-19). In Poland, there were cases in which the state enterprise managing publicly owned real estate adopted unlawful ad-hoc measures to prevent an NGO from acquiring an office (KI-1). The rhetoric of state actors towards harm reduction services can, at times, be adversarial (KI-16).

\subsection{System stability}

Czechia is characterized by relatively high stability, both regarding the drug policy system (Csete, 2012) and its funding frameworks (KI-13). Nevertheless, multisource and tender-based funding schemes cause a degree of uncertainty and some concerns for the future (KI-13).

4 In Poland, there has been no separate anti-drug strategy since 2016, and drug-related issues are dealt with under the more comprehensive National Program for Health. 
In Hungary, by contrast, the penal code on psychoactive substances changes frequently. Moreover, since 2010, the broader policy field and financing system of drug policy (and especially harm reduction) has also undergone radical and unpredictable changes (KI-6).

The policy system in Poland has been more stable, with criminal regulations on illicit drugs rarely changing, and with the most notable change taking place in 2000, which introduced penalties for drug possession (Konikowska-Kuczyñska, 2008). Regarding the funding system, a major change supporting harm reduction NGOs was recently done introducing longer, 3-years projects (KI-4).

In Slovakia, similarly, drug policy and regulation on drugs have been stable (Csete, 2012), as has the funding framework for harm reduction (KI-16).

\subsection{Mechanisms for involving NGOs in policy formulation and design}

Data on Czechia suggest that NGOs are meaningfully involved in policy formulation and design, most notably by their representation in the Government Council for Drug Policy Coordination (Government of the Czech Republic, 2016; KI-15).

In Hungary there is no evidence of mechanisms involving NGOs in policy formulation. On the contrary, some existing mechanisms were abolished by the Government and certain harm reduction organizations were excluded from participating in the ones remaining (KI-6). Unlike earlier, NGOs nowadays feel so threatened that they are afraid to speak or conduct advocacy activities (KI-9).

In Poland, NGOs attempt to affect policy design mainly through advocacy (KI-4). The results of these efforts are disappointing, however, and it seems decision-makers largely ignore NGO requests or suggestions.

Similarly, the Slovak Government seems unwilling to involve NGO representatives in shaping policy. Although organizations are sometimes invited to formal and informal discussions with the state, it seems from the data that these approaches are more symbolic than representative of any genuine interest in meaningfully involving NGOs in policy design (KI-19).

\subsection{Mechanisms for involving NGOs in policy implementation}

In all four countries, the implementation of examined harm reduction services is done by NGOs selected by governments and based on service delivery contracts.

In Czechia, organizations are well-established and have sound relationships with the Government actors regarding implementation of harm reduction services (KI-13).

In Hungary, the general atmosphere around harm reduction hinders service delivery (KI-9). It seems that harm reduction no longer appears in tender announcements. Two major needle exchange programs were removed from their offices based on politically driven decisions (KI-11).

In Poland, the main problematic issue regarding policy implementation seems to be interference from law enforcement. Firstly, the police presence around services can deter clients, while strict regulations, including incarceration of service clients, 
disrupts relationship continuity (KI-2). Moreover, implementation of services can be hindered due to challenges in securing premises ${ }^{5}(\mathrm{KI}-3)$.

In Slovakia, the police presence can have a negative impact on policy implementation, primarily through stigmatization of clients and occasional violence towards them (KI-17). Moreover, some actions by certain municipalities hinder the work of harm reduction NGOs (KI-16).

The examples from Poland and Slovakia, although indeed presenting hostile actions of some state actors, seem to be however scattered and arbitrary rather than representing systemic features.

\subsection{Indirect resources}

In all four countries, mechanisms are in place to reduce the taxes paid by NGOs, with varying levels of eligibility restrictions. Moreover, in all four countries, under certain conditions, NGOs may receive donations in the form of income tax relief (individuals and/or companies can donate part of their tax payment to NGOs).

In Czechia, individuals and corporations can donate $2-15 \%$ of their income, which is then deducted from their taxable income (Navratil and Pejcal, 2017, p. 47).

In Poland, citizens can donate $1 \%$ of their personal income tax (PIT) to eligible NGOs (Ekiert, Kubik and Wenzel, 2017, p. 78), while in Slovakia, 2\% donations are possible from PIT and CIT (corporate income tax) (Strecansky, 2017, p. 96).

In Hungary, the scheme is much less generous. Individuals can donate $1 \%$ of their income tax to a selected eligible organization. However, the eligibility criteria were significantly restricted in 2011 (Kuti, 2017, p. 61). The Hungarian Government even blocked the most significant international, non-state-controlled source of funding for NGOs (Nielsen, 2014), resulting in these funds being withdrawn from the country altogether.

Similar attempts were made by the Polish Government, but without success (Ambroziak, 2018).

\subsection{Direct resources}

Although the available data on direct resources is, in many cases, highly outdated and/or scarce, based on available information it seems that the amount of direct resources for harm reduction NGOs is the highest in Czechia. In 2017, over 66 million Euro was spent on drug policy in general ( $0.03 \%$ of the GDP), and the largest proportion of demand reduction budget (27 million Euro) was granted to treatment and harm reduction (EMCDDA, 2019). According to the data collected from 17 organizations operating nearly half of the country's low-threshold harm reduction programs, the average budget per organization equaled 381,000 Euro in 2017. Although

5 Organizations are responsible for securing the premises for service delivery; state-owned real estate is not governed by the same body that grants resources and service-delivery contracts, and there is no coordination; sometimes, therefore, NGOs receive funding but are not granted premises to rent. 
these resources are not sufficient for any investments, they do enable services to run smoothly (KI-13). The allocation of resources seems to be fair and transparent, based on the assessment of needs and merits.

By contrast, the amount of financial resources in Hungary is very low: organizations constantly face financial difficulties and struggle to survive as a result of drastic budget cuts and the practical elimination of 'harm reduction' as a category from all frameworks (tenders, projects) of state financing for drug policy (KI-6). The most up-to-date official data are from 2007, when public expenditure on drug policy reached 39 million Euro ( $0.04 \%$ of GDP), of which approximately 9 million was spent on demand reduction, including 1.5 million allocated to harm reduction (EMCDDA, 2018a). Given the aforementioned cuts in 2011, it can be assumed that current budget for harm reduction NGOs is significantly lower. Indeed, the data collected from four (out of 30) service-delivery NGOs show that the average budget per organization was 45,000 Euro in 2017. Resource allocation is ideologically driven and based on political bias (KI-11).

In Poland the amount of resources is slightly higher, so larger organizations can offer a broad range of services and have long opening hours (KI-4). The drug policy budget in 2015 was 35 million Euro ( $0.01 \%$ of GDP), but information on how resources were distributed within the policy field is not available (EMCDDA, 2018b). Data from three (out of 12) NGOs show that the average organization's budget in 2017 equaled slightly over 56,000 Euro. The allocation of resources favors organizations providing long-term in-patient treatment services. Although this amounts to a bias, it seems to reflect a broader conservative, abstinence-oriented paradigm of drug policy, rather than an illiberal turn.

Direct resources in Slovakia are more generous than in Hungary and Poland, yet services can afford to open only a few days per week for a few hours. The lack of upto-date official data on public expenditure (most recently 2006, 0.05\% of GDP, according to EMCDDA, 2018c) indicates rather low Government interest in this policy field. The data from all harm reduction NGOs operating in Slovakia show that the average budget per organization in 2017 was approximately 135,000 euros. The only reported bias in resources allocation is a result of alleged corruption in the Ministry (KI-20).

\subsection{Joint operating procedures}

In our understanding, autonomy refers to the number and scope of joint/adjusted operational procedures between various actors involved in CG. No such procedures exist at an organizational level in any of the four countries examined.

In Czechia, attempts have been made to establish such procedures with the prison service (KI-13).

In Hungary, there are a few activities to develop joint procedures between harm reduction and (public) addiction treatment services (KI-9).

Polish data suggest a lack of any joint or compatible operating procedures between sectors. On the contrary, it seems that attempts to cooperate with some institutions, for example hospitals, meet with outright hostility (KI-4). 
In Slovakia, similar to Hungary, NGOs attempt to establish relationships with healthcare providers (KI-19).

The above-mentioned attempts to establish relationships between NGOs and other health and social care institutions are, however, based on personal relationships. Institutional forms of adjusted operational procedures are absent in all examined countries.

\subsection{Trust-building: policies and government activities affecting trust}

Trust-building activities are present in Czechia (KI-14). Communication between NGOs and the Government seems frequent and open, both sides show good intentions and a commitment to cooperation (KI-13).

The Hungarian environment is characterized by a very low level of trust. Some government activities even undermine trust (KI-11). The Government's behavior towards NGOs is sometimes hostile (KI-7).

In Poland, trust-building activities seem to be present at local government level, though these are often restricted by state actors' concerns about their position (KI-3). Law enforcement also seems to be exhibiting trust-building attitudes (KI-1). On the other hand, strict control over NGOs activities can undermine trust (KI-3).

In Slovakia, some trust-building activities are present, mainly in the form of communication (KI-17). Showing commitment to the relationship and to the issue being addressed is also present to a certain extent (KI-16).

Table 2: Summary of empirical findings

\begin{tabular}{lcccc}
\hline Dimension / Country & Czechia & Hungary & Poland & Slovakia \\
\hline Operational space & + & - & 0 & 0 \\
System stability & + & - & + & + \\
NGO involvement in policy design & + & - & 0 & 0 \\
NGO involvement in policy implementation & + & - & + & + \\
Indirect resources & + & - & + & + \\
Direct resources & + & - & 0 & + \\
Joint operating procedures & 0 & 0 & 0 & 0 \\
Trust-building & + & - & + & +
\end{tabular}

Note: The cells in the table summarize the above empirical findings as follows: + stands for pro-collaborative, 0 for neutral, and - for anti-collaborative governance regimes.

\section{Conclusions and discussion}

Three findings in particular are central to our research objective.

Firstly, taking an approach assuming significant role of governments in shaping CG (as opposed to spontaneous occurrence), and including possible neutral and hostile government attitudes towards CG (as opposed to different levels pro-collaborative attitudes existing in the scholarship hitherto), we have developed a conceptual classification of CGRs and operationalized them along a number of observable features. 
Secondly, only Czechia unquestionably exhibits the features of a pro-collaborative regime. Poland and Slovakia, meanwhile, are located between pro-collaborative and neutral CGRs. Importantly, however, one case - Hungary - indisputably qualifies as an anti-collaborative governance regime - a regime that is distinctly different from the customary 'neutral CGR' characteristic for many countries in CEE (and elsewhere). This 'anti-collaborative regime' predominantly differs from earlier ones in that it openly and deliberately impedes harm reduction NGOs.

Such an anti-collaborative regime involves blatant, harsh intimidation of selected NGOs. A more serious instrument of this policy is criminal law. While in some cases certain NGO activities may be directly criminalized, in other cases the legal framework creates ambiguity, allowing authorities to interpret some NGO activities as potentially criminal (e.g. distributing sterile needles may be seen as being an 'accessory to crime'). The legal and policy framework is subject to frequent, unpredictable and/or uncontrollable changes. There are no institutional mechanisms for involving NGOs in policy formulation. Moreover, government policy consciously eliminates any pre-existing mechanisms. Service delivery through NGOs is blocked through semi-formal (sometimes even illegal) administrative measures. The anti-collaborative regime includes funding mechanisms that not only lead to severe under-resourcing of NGOs but involve a strongly and openly selective funding process, favoring NGOs aligned with government ideology. Moreover, conscious measures are undertaken by the government to cut the funding of hostile NGOs received from other, non-governmental sources. As for direct resources, services and operations are directly funded at the minimum level possible, which is sometimes zero. Finally, not only is there a lack of trust between governmental and non-governmental parties, trust-building activities are absent, but there are even conscious government activities deliberately undermining trust.

The primary motive for doing so seems to be ideological (rather than material): the governing forces equate harm reduction activities with approval of the use of illicit drugs, and thus as a means of promoting 'liberal' and 'anti-patriotic' worldviews and lifestyles.

Thirdly, but no less importantly, this anti-collaborative regime appears in only one of our two illiberal cases, namely Hungary, while it is absent from Poland. Nevertheless, although not covered by our empirical research, it seems justified to mention that an anti-collaborative regime very similar to the one identified in Hungary is also present in Poland, not in harm reduction policy, but in reproductive and women's rights, and the services and advocacy activities attached to them.

In sum, it seems that the specifically anti-collaborative element of CG regimes in CEE - where they exist at all - does not appear uniformly across different policy areas. On the contrary, large segments of the NGO community and the corresponding CG arrangements operate practically untouched by illiberalism. The illiberal doctrine is found only in a few policy areas, which embody, ideologically and politically, an antithesis of the worldviews held by the ruling political parties. 
These policy areas may also vary in space and time. Very recently in Hungary, for example, migration policy emerged as the latest target of the ever-harsher governmental crackdown (even including the criminalization of university study programs and public information campaigns dealing with migration) (CEU Suspends Education Programs for Registered Refugees and Asylum Seekers, 2018). This situation opens up interesting and progressive avenues of investigation, including, most prominently, exploring and explaining this specific aspect of anti-collaborative regimes (in sharp contrast to, for example, local and territorial governance). The implications for the capacity-building efforts of (national as well as international/European) NGOs might, moreover, also be of significant practical relevance.

\section{References:}

1. Ágh, A., 'De-Europeanization and De-Democratization Trends in ECE: From the Potemkin Democracy to the Elected Autocracy in Hungary', 2015, fournal of Comparative Politics, vol. 8, no. 2, pp. 4-26.

2. Ambroziak, A., 'PiS obszedł się smakiem. 30 mln euro Funduszy Norweskich zarząadzać będą niezależne organizacje' [PiS Had Good Taste. The EUR 30 Million of Norwegian Funds Will Be Managed by Independent Organizations], October 30, 2018, OKO Press [blog article], [Online] available at https://oko.press/pis-obszedl-sie-smakiem-30-mln-euro-fun duszy-norweskich-zarzadzac-beda-niezalezne-organizacje/, accessed on November 12, 2020.

3. Ansell, C. and Gash, A., 'Collaborative Governance in Theory and Practice', 2007, fournal of Public Administration Research and Theory, vol. 18, no. 4, pp. 543-571.

4. Bedwell, W.L., Wildman, J.L., Diaz Granados, D., Salazar, M., Kramer, W.S. and Salas, E., 'Collaboration at Work: An Integrative Multilevel Conceptualization', 2012, Human Resource Management Review, vol. 22, no. 2, pp. 128-145.

5. Bingham, L.B., 'Collaborative Governance', in Bevir, M. (ed.), The SAGE Handbook of Governance, London: Sage Publications, 2011, pp. 386-401.

6. Blatter, J. and Haverland, M., 'Congruence Analysis', in Blatter, J. and Haverland, M. (eds.), Designing Case Studies: Explanatory Approaches in Small-N Research, New York: Palgrave Macmillan, 2012, pp. 144-204.

7. Bochsler, D. and Juon, A., 'Authoritarian Footprints in Central and Eastern Europe', 2019, East European Politics, vol. 36, no. 2, pp. 167-187.

8. Borgh, C. van der and Terwindt, C., 'Shrinking Operational Space of NGOs - A Framework of Analysis', 2012, Development in Practice, vol. 22, no. 8, pp. 1065-1081.

9. Börzel, T.A., 'Why You Don't Always Get What You Want: EU Enlargement and Civil Society in Central and Eastern Europe', 2010, Acta Politica, vol. 45, no. 1-2, pp. 1-10.

10. Brandsen, T. and Hout, E. van, 'Co-management in Public Service Networks: The Organizational Effects', 2006, Public Management Review, vol. 8, no. 4, pp. 537-549.

11. Bryson, J.M., Crosby, B.C. and Stone, M.M., 'The Design and Implementation of CrossSector Collaborations: Propositions from the Literature', 2006, Public Administration Review, vol. 66, no. s1, pp. 44-55.

12. CEU (Central European University), 'CEU Suspends Education Programs for Registered Refugees and Asylum Seekers' [press release], August 28, 2018, [Online] available at 
https://www.ceu.edu/article/2018-08-28/ceu-suspends-education-programs-registeredrefugees-and-asylum-seekers, accessed on November 12, 2020.

13. Cianetti, L., Dawson, J. and Hanley, S., 'Rethinking 'Democratic Backsliding' in Central and Eastern Europe - Looking beyond Hungary and Poland', 2018, East European Politics, vol. 34, no. 3, pp. 243-256.

14. Cooley, A., 'Countering Democratic Norms', 2015, Journal of Democracy, vol. 26, no. 3, pp. 49-63.

15. Council of Ministers of Poland, 'Narodowy Program Zdrowia na lata 2011-2016' [National Health Program for 2011-2016], 2016, Journal of Laws no. 2016, item 1492, [Online] available at http://dziennikustaw.gov.pl/DU/2016/1492/1, accessed on November 12, 2020.

16. Csete, J., A Balancing Act. Policymaking on Illicit Drugs in the Czech Republic, New York: Open Society Foundations, 2012.

17. Ekiert, G., 'The Illiberal Challenge in Post-Communist Europe: Surprises and Puzzles', 2012, Taiwan fournal of Democracy, vol. 8, no. 2, pp. 63-77.

18. Ekiert, G., Kubik, J. and Wenzel, M., 'Civil Society and Three Dimensions of Inequality in Post-1989 Poland', 2017, Comparative Politics, vol. 49, no. 3, pp. 331-350.

19. EMCDDA (European Monitoring Center for Drugs and Drug Addiction), 'Public Expenditure in Hungary', 2018a, [Online] available at http://www.emcdda.europa.eu/countries/ drug-reports/2018/hungary/public-expenditure_en, accessed on November 12, 2020.

20. EMCDDA (European Monitoring Center for Drugs and Drug Addiction), 'Public Expenditure in Poland', 2018b, [Online] available at http://www.emcdda.europa.eu/countries/ drug-reports/2018/poland/public-expenditure_en, accessed on November 12, 2020.

21. EMCDDA (European Monitoring Center for Drugs and Drug Addiction), 'Public Expenditure in Slovakia', 2018c, [Online] available at http://www.emcdda.europa.eu/countries/ drug-reports/2018/slovakia/public-expenditure_en, accessed on November 12, 2020.

22. EMCDDA (European Monitoring Center for Drugs and Drug Addiction), 'Public Expenditure in the Czech Republic', 2019, [Online] available at http://www.emcdda.europa.eu/ countries/drug-reports/2019/czechia/public-expenditure_en, accessed on November 12, 2020.

23. Emerson, K. and Nabatchi, T., Collaborative Governance Regimes, Georgetown University Press, 2015.

24. Emerson, K., Nabatchi, T. and Balogh, S., 'An Integrative Framework for Collaborative Governance', 2012, Journal of Public Administration Research and Theory, vol. 22, no. 1, pp. 1-29.

25. Foa, R.S. and Mounk, Y., 'The Signs of Deconsolidation', 2017, fournal of Democracy, vol. 28 , no. 1 , pp. $5-15$.

26. Freedom House, 'Nations in Transit 2020: Dropping the Democratic Façade', 2020, [Online] available at https:/freedomhouse.org/sites/default/files/2020-04/05062020_FH_NIT2020_ vfinal.pdf, accessed on November 12, 2020.

27. Fric, P. and Bútora, M., 'The Role of the Nonprofit Sector in Public Policy', in Potucek, M., Leloup, L.T, Jenei, G. and Váradi, L. (eds.), Public Policy in Central and Eastern Europe: Theories, Methods, Practices, NISPAcee, 2003, pp. 145-172.

28. Gerő, M. and Kerényi, S., 'Anti-Soros Rallies and Blazing EU Flags. Civil Society and Social Movements between Populism and Democracy in Central and Eastern Europe', 2017, Socio. $h u$, Special Issue in English, no. 5, pp. 1-6. 
29. Goodman, L.A., 'Snowball Sampling', 1961, The Annals of Mathematical Statistics, vol. 32, no. 1, pp. 148-170.

30. Government of the Czech Republic, 'The National Drug Policy Strategy for the Period 2010 to 2018', approved by Resolution No. 340 on May 10, 2010, [Online] available at https:// www.drogy-info.cz/data/obj_files/1606/627/National_Drug_Polici_Strategy_CzechRepublic_2010.2018_v2.pdf, accessed on November 12, 2020.

31. Government of the Czech Republic, 'The Statute of the Government Council for Drug Policy Coordination', approved by Resolution No. 697 on July 27, 2016, [Online] available at https://www.vlada.cz/assets/ppov/protidrogova-politika/The_Statute_of_the_GCDPC. pdf, accessed on November 12, 2020.

32. Gray, B. and Wood, D.J., 'Collaborative Alliances: Moving from Practice to Theory', 1991, The Journal of Applied Behavioral Science, vol. 27, no. 1, pp. 3-22.

33. Grzebalska, W. and Peto, A., 'The Gendered Modus Operandi of the Illiberal Transformation in Hungary and Poland', 2018, Women's Studies International Forum, vol. 68, pp. 164-172.

34. Hajnal, G. and Rosta, M., 'A New Doctrine in the Making? Doctrinal Foundations of SubNational Governance Reforms in Hungary (2010-2014)', 2016, Administration \& Society, vol. 51, no. 3, pp. 404-430.

35. Hak, T. and Dul, J., 'Pattern Matching', in Mills, A.J., Durepos, G. and Wiebe, E. (eds.), Encyclopedia of Case Study Research, Blatter-Haverland, 2012.

36. Head, B.W. and Alford, J., 'Wicked Problems: Implications for Public Policy and Management', 2015, Administration \& Society, vol. 47, no. 6, pp. 711-739.

37. Head, B.W., 'Wicked Problems in Public Policy', 2008, Public Policy, vol. 3, no. 2, pp. 101-118.

38. Hosmer, L.T., 'Trust: The Connecting Link between Organizational Theory and Philosophical Ethics', 1995, The Academy of Management Review, vol. 20, no. 2, pp. 379-403.

39. Howard, M.M., 'The Weakness of Postcommunist Civil Society', 2003, fournal of Democracy, vol. 13, no. 1, pp. 157-169.

40. Howlett, M., 'From the 'Old' to the 'New' Policy Design: Design Thinking beyond Markets and Collaborative Governance', 2014, Policy Sciences, vol. 47, no. 3, pp. 187-207.

41. Hungarian Parliament, '2017. Évi LXXVI. törvény a külföldről támogatott szervezetek átláthatóságáról, no. LXXVI’ [Year LXXVI. Act on the Transparency of Foreign-Supported Organizations, no. LXXVI], 2017, [Online] available at https://net.jogtar.hu/jogsz abaly?dbnum=1\&docid=A1700076.TV, accessed on November 12, 2020.

42. Hungarian Parliament, 'The National Anti-Drug Strategy 2013-2020', Parliament Resolution No. 80/2013 (X. 16.), 2013, [Online] available at http://www.emcdda.europa. eu/system/files/attachments/9079/Department\%20of\%20Human\%20Capactities\%2C\%20 Hungary\%20\%282013\%29\%20National\%20Anti-Drug\%20Strategy\%202013-2020.pdf, accessed on November 12, 2020.

43. ICNL (International Center for Not-for-Profit Law), 'Nonprofit Law in Czech Republic', 2019a, [Online] available at https://www.cof.org/sites/default/files/documents/files/Cze ch\%20Republic/Czech-Republic-Note-June-2019.pdf, accessed on November 12, 2020.

44. ICNL (International Center for Not-for-Profit Law), 'Nonprofit Law in Poland', 2019b, [Online] available at https://www.cof.org/sites/default/files/Poland-201910.pdf, accessed on November 12, 2020. 
45. ICNL (International Center for Not-for-Profit Law), 'Nonprofit Law in Slovakia', 2019c, [Online] available at https://www.cof.org/sites/default/files/Slovakia-201905.pdf, accessed on November 12, 2020.

46. Konikowska-Kuczyñska, J., 'Odpowiedzialność karna za posiadanie narkotyków’ [Criminal Liability for Drug Possession], 2008, Alkoholizm i Narkomania, vol. 21, no. 3, pp. 311-322.

47. Kuti, E., 'Country Report: Hungary', in Vandor, P., Traxler, N., Millner, R. and Meyer, M. (eds.), Civil Society in Central and Eastern Europe: Challenges and Opportunities, Viena: ERSTE Foundation, 2017, pp. 58-75.

48. Landman, T., Issues and Methods in Comparative Politics: An Introduction, New York: Routledge, 2009.

49. Lührmann, A. and Lindberg, S.I., 'A Third Wave of Autocratization Is Here: What is New About It?’, 2019, Democratization, vol. 26, no. 7, pp. 1095-1113.

50. McNamara, M., 'Starting to Untangle the Web of Cooperation, Coordination, and Collaboration: A Framework for Public Managers', 2012, International fournal of Public Administration, vol. 35, no. 6, pp. 389-401.

51. Ministry of Health of the Slovak Republic, 'National Anti-Drug Strategy of the Slovak Republic for the period 2013-2020’, 2013, [Online] available at http://www.emcdda.europa. eu/system/files/attachments/9077/Ministry\%20of\%20Health\%20Of\%20the\%20Slovak\%20 Republic\%20\%282013\%29\%20National\%20Antidrug\%20Strategy\%20of\%20the\%20Slovak\%20 Republic\%202013-2020.pdf, accessed on November 12, 2020.

52. Navratil, J. and Pejcal, J., 'Country Report: Czech Republic', in Vandor, P.J., Traxler, N., Millner, R. and Meyer, M. (eds.), Civil Society in Central and Eastern Europe: Challenges and Opportunities, Viena: ERSTE Foundation, 2017, pp. 43-57.

53. Nielsen, N., 'Hungary Raids Norway-backed NGOs', EU Observer, September 10, 2014, [Online] available at https://euobserver.com/political/125537, accessed on November 12, 2020.

54. Osborne, S.P. and Strokosch, K., 'It Takes Two to Tango? Understanding the Co-production of Public Services by Integrating the Services Management and Public Administration Perspectives', 2013, British fournal of Management, vol. 24, no. S1, pp. S31-S47.

55. Osborne, S.P., 'The New Public Governance?', 2006, Public Management Review, vol. 8, no. 3, pp. 377-387.

56. Parliament of the Czech Republic, Zákon ze dne 14. Března 2006 o sociálních službách, no. 108/2006 [Act of 14 March 2006 on social services, no. 108/2006].

57. Pestoff, V., 'Co-production and Third Sector Social Services in Europe: Some Concepts and Evidence', 2012, VOLUNTAS: International fournal of Voluntary and Nonprofit Organizations, vol. 23, no. 4, pp. 1102-1118.

58. Provan, K.G. and Milward, H.B., 'A Preliminary Theory of Interorganizational Network Effectiveness: A Comparative Study of Four Community Mental Health Systems', 1995, Administrative Science Quarterly, vol. 40, no. 1, pp. 1-33.

59. Rees, J., Mullins, D. and Bovaird, T., 'Third Sector Partnerships for Public Service Delivery: An Evidence Review', TSRC (Third Sector Research Center), Working Paper No. 60, 2012, [Online] available at https:/www.birmingham.ac.uk/Documents/college-social-sciences/ social-policy/tsrc/working-papers/working-paper-60.pdf, accessed on November 12, 2020. 
60. Rees, N. and Paraskevopoulos, C.J., 'Europeanization of Policy-Making and Domestic Governance Structures in Regional Policy: Cohesion and CEE Countries', in Paraskevopoulos, C.J., Getimēs, P. and Rees, N., Adapting to EU Multi-Level Governance: Regional and Environmental Policies in Cohesion and CEE Countries, Routledge, 2006, pp. 179-205.

61. Rupnik, J. and Zielonka, J., 'Introduction: The State of Democracy 20 Years on: Domestic and External Factors', 2012, East European Politics and Societies, vol. 27, no. 3, pp. 3-25.

62. Sharfman, M.P., Gray, B. and Yan, A., 'The Context of Interorganizational Collaboration in the Garment Industry: An Institutional Perspective', 1991, The fournal of Applied Behavioral Science, vol. 27, no. 2, pp. 181-208.

63. Strecansky, B., 'Country Report: Slovakia', in Vandor, P., Traxler, N., Millner, R. and Meyer, M. (eds.), Civil Society in Central and Eastern Europe: Challenges and Opportunities, Viena: ERSTE Foundation, 2017, pp. 92-109.

64. Tongco, D.C., 'Purposive Sampling as a Tool for Informant Selection', 2007, Ethnobotany Research and Applications, vol. 5, pp. 147-158.

65. Yin, R.K., Applications of Case Study Research, London: Sage Publications, 2003.

66. Zakaria, F., 'The Rise of Illiberal Democracy', 1997, Foreign Affairs, vol. 76, no. 6, pp. 22-43. 